\title{
TRACING THE IMPINTS OF JAINISM IN VIETNAM
}

\section{LE THI SINH HIEN}

University of Social Sciences and Humanities, Vietnam National University, Ho Chi Minh City, Vietnam

Jainism has been the oldest and most peaceful religion in the world Jainism started in India and became one of the oldest religions and philosophies of this country as compared to others in there Moreover, it is also considered the global religion in the modern time There are now large Jainism communities in the UK, Belgium, United States, Canada, and many small Jainism communities in towns and farms in Europe and North America It is estimated that there have been more than 4.5 million Jains worldwide In the early times, Jainism had been spread all over to many ancient kingdoms of the West as well as the East such as ancient Greece, Scandinavia, Caspia, Ethiopia, Egypt, Sumer, Babylon, Syria, Persia, Turkey, Arabia, Burma, Sri Lanka, Tibet, Afganistan, Indonesia, Nepal, Bhutan, Japan, Thai Land and Cambodia Many vestiges of Sramana culture have been found in these countries

As we know, Vietnamese culture has been influenced by Indian one due to the commercial contacts in the beginning of the century after Christ Numerous historical sites in Vietnam prove this contact and various Indian cultural imprints have been found by archaeologist and historians such as the findings of Louis Malleret on La civilization materielle d' Oc Eo published in two volumes in Ha Noi in 1970 and the work of G. Coedes on Ancient Indian Colonies in the Far East translated into Vietnamese and published in 2008 Their works lead me to wonder whether Jainism was spread to Vietnam or not? Did the Sramana culture use to exist in Vietnam? and why? When Jainism possesses characteristics of a global religion with cultural values:"cultural diversification, value pluralism, balanced life, harmony with nature, eco-friendly, non-violence, non-polar respect, gender equality, development of education and family happiness, etc." [Mark Juergensmeyer, 2012, p.8]. These are very close to and suitable with Vietnamese culture, which also has the same religious tolerance as Jainism does Therefore, this paper would like to trace the imprints of Jainism in Vietnam, whether Jainism was available there or not and why by studying some of its archaeological sites like Champa, Oc Eo and Cat Tien
\end{abstract}

KEYWORDS: Jainism, Imprints of Jainism, Vietnam, Oc Eo, Champa \& Cat Tien

Received: Jun 07, 2019; Accepted: Jun 27, 2019; Published: Jul 16, 2019; Paper Id.: IJHRDEC20191

\section{INTRODUCTION TO JAINISM}

The historical origin of Jainism can be traced back to the teachings of Vardhaman Mahavira, the $24^{\text {th }}$ Tirthankara The first of the 24 Tirthankaras was Rishabhanatha Dev or Rishabhadeva (Rishabha means best, most excellent) In Jainism, he belonged to the House of Iksavaku (House of the Sun), born into an Iksavaku clan He was believed to have lived before civilization developed He taught people how to do agriculture, to domesticate animals, to cook and the like Rishabhadeva was considered the founder of Jainism in the present time cycle and he was born in the fifth generation after Svayambhu Manu According to Jain time cycle, the existence of Rishabhadeva cannot be traced, he must have lived maybe from incalculable time But we can trace it through Indian literature like Rgveda, the three Vedas, Upanishads and Puranas [Gokul Prasad Jain 2018, p 1]. Based on relics of Jainism, archaeologists place the period of Rishabhadeva at 9,000 B.C.E But if the time of Svayambhu Manu was estimated 
at 29,000 ago, his fifth generation, i. e time of Rishabhadeva should be about 27,000 B.C.E Parshwanath, son of king Ashwasena, was born in the $8^{\text {th }}$ century BCE, believed to be the $23^{\text {rd }}$ Tirthankara He was said to have renounced all luxuries, indulgences and society to become a hermit Through renunciation and meditation, he attained enlightenment and immortality Parshwanath preached people 4 principles for leading a peaceful life The fifth principle was taught by Vardhaman, the $24^{\text {th }}$ Tirthankara The 5 principles are Ahimsa (non-violence), Satya (truth), Astheya (do not steal), Aparigraha (do not own property) and Bramhacharya (celibacy) Complying with these five principles in life, Jains also practice austerity, meditation and tolerance Vardhaman (599 - 527 BC) was born in Vaishali to a royal and notable family, his father was king of the Gnatrika tribe and his mother was a princess of the Republic Licchavi He became a jina and was known as Mahavira (Great Hero) In Sanskrit, jina means 'victory', it is a fight against the passion, discomfort of the body, to gain wisdom and purity of mind, i.e it refers to the one who has complete control over everything Followers of Jainism are called Jains Mahavira taught 5 vows to the people based on the principles of Jainism He also preached 3 principles of behavior to the people to be known as the Triratnas (ratnatraya): Samyag darshan (right faith), Samyag Gyan (right knowledge) and Samyag Charitra right practice) These moral standards are considered as three precious jewels

Like Buddhism, Jainism was founded by members of the warrior caste, part of a social upheaval with opposition to Aryan hegemony and Brahmin priestly dominance Jainism rejects the authority of the Hindu Vedas It seeks an individual rather than mass social approach to the 'Ultimate Truth' In Jainism, Atman and Brahman are one Jainism advocates atheism but does not reject the existence of God completely It places God at a lower level than Jina and denies the role of God in the daily affairs of people Because they believe in karma, which is a very important concept of Jainism According to karma doctrine, a human being can attain salvation only through good acts To attain enlightenment, the soul should free itself from the bondage of the body The Jains believe that everything possesses a soul and it is only through the purification of the soul one can achieve freedom and attain nirvana For them purification is possible through meditation, fasting and punishment of the body

Around the beginning of the 3rd century BC, Jainism began to split into two sects due to differences in principles and rules for believers: Digambara (not wearing costumes) and Shwetembara (wearing white costumes) Jainism believes that the universe includes the spiritual world (Jiva) and the physical world (Ajiva) Jiva is invisible, formless, intangible, no gender, possesses the qualities of infiniteness and creates tangible and intangible matters Soul and material elements (earth, water, fire, air) have created a living body, but the soul always wants to escape from the body, to return to its spiritual world Jains believe that the body always creates the cycle ofbirth, death, and rebirth I .e karma Karma can be destroyed through a process of renunciation, including fasting, controlling ambition, living in quiet places, serving, learning, and meditating This is the moral foundation that must be followed and cultivated by Jainism followers The ideal and faith of Jains is to help the soul escape from the body to return to the world of pure souls That is the unity of truth, goodness and beauty Austerity is a common form of Jainism's cultivation practice Austerity is followed by practicing vegetarianism, avoiding violent actions, telling the truth, not stealing, not killing, leading a single life There should be no property and avoid excessive sexual activities Yoga is a form of material cultivation and meditation of the Jains, this is a means to attain omniscience and thus liberation (Moksha) By practicing yoga, it cultivates practical knowledge, true beliefs and pure behavior, because it is closely related to the three jewels: right knowledge, right belief and right behavior Jainism followers strictly practice ahimsa not only in action but also in thought and mind They do no harm to human beings as well as small beings and organisms such as insects, mosquitoes, flies, etc Ascetic life is highly valued and leading an ascetic life is one of the practices of Sramana culture. Jainism is the oldest and indigenous religion of India before the invasions of 
Aryans [Jain 2018, p.2] Jain culture has been rooting in Indian subcontinent since the dawn of human civilization and it is the foundation on which Indian diversified cultures are based India was named Bharata after Cakravarti Bharata, who was son of Risabhadeva, the first Tirthankara The ascetic culture of India is called Sramana one in Sanskrit

\section{SPREAD OF JAINISM OVERINDIAN SUBCONTINENT}

In India, although we know Risabhadeva to be the first Tirthankara and founder of Jainism in the present time circle, and his time of existence was long time ago, where he used to live and preached people has not been defined yet However, Jainism was recognized to be the most popular religion in the metropolitan town named Kalibanga, which situated on the bank of River Saraswati in North India around the $6^{\text {th }}$ century B. C That archaeologists found the idols of Arhat Risabhadeva in standing Kayotsarga posture and Suparaswanath with five headed serpent and many naked sculptures of Jain monks at the excavation sites of Indus Valley civilization proved the existence of Jainism in the region Magadha was believed to be the center of Jainism at the time King of Maurya dynasty like Asoka was claimed to be a follower of Jainism before he converted to Buddhism Mahavira, the $24^{\text {th }}$ Tirthankara, used to preach his thoughts in the villages and towns around Gange and Yamuna rivers, then he travelled towards the western India He attained nirvana in Bihar at the age of 72 based on some archaeological evidence and literature Alexander and his army were said to have found Nirgrantha Sramanas wandering in Gandhara, Taksasila, Punjab and Sindha They called these monks Gymnosophists which means Sramana i. e Jain munis belonging to Digambara sect Some Jain munis of Indus valley were also called forest dwellers (Hilavai) [Jain 2018, p.18].

Lord Aristanemi was said to be the $22^{\text {nd }}$ Tirthankara, who was the son of Samudravijaya an uncle to Krishna Maharaja and lived around 3000 B.C. E as he was a cousin of Lord Krishna and his contemporary He was the person to oppose serving meat as food in royal weddings By seeing animals captured, to-be butchered and having no purpose in mundane life, prince Aristanemi rejected marriage and became an ascetic (Nude Jain monk) [Jain 2018, p2]. Jainism first started in the North India then spread to the South by the Jains who are traders and ascetic monks There are many Jain heritages and temples in Tamil Nadu today.

Many centuries later, there was a famine in Magadha and it led to mass migration of the population to South India (present day Karnataka) and after some time, another migration took place to Gujarat (Girnar) The first group was called Svetambars because they started wearing white clothes, whereas the other ones (Digambars) These were strict and not willing to change A third influential group developed after migration from Bihar to near Mathura, which tried to patch up between these two groups for a long time Udaygiri (Orisa) was also one of the important Jain centres In the olden days, this religion was also practised inSri Lanka Allof this happened approximately 2000 years back ${ }^{1}$.

Like Buddhism, the Jains build numerous stupas, temples, viharas, palaces, and forts across Indian subcontinent but most of them disappeared or were destroyed and razed down to the ground Some of them still remain today as a lively evidence to challenge the world We can find the great Jain temples and sculpture monuments in Karnataka, Maharashtra, Rajasthan, and Tamil Nadu In Karnataka, the presence of 57-feet high statue of Lord Bahubali at Shravanabelagola temple proved the spread of Jainism over the South India Bahubali was believed to be the son of the first Tirthankara

\footnotetext{
${ }^{1}$ http://www.engr.mun.ca/ asharan/bihar/jainism.pdf

${ }^{1}$ http://www.engr.mun.ca/ asharan/bihar/jainism.pdf
} 
Risabhadeva $^{2}$ His statue was built by the Western Ganga Dynasty in 981 A. D Unlike Buddhism whose temples are free-standing temples and rock-cut caves, Jainism possesses many complex viharas called temple-cities on hills All are dedicated to the worship of Tirthankaras, for example, Adinatha temple at Ranakpur was built to dedicate to Risabhadeva, the first Tirthankara of Jainism Luna Vasahi temple built in 1230 A.D in Gujarat was dedicated to Neminath, the $21^{\text {st }}$ Tirthankara, Parshanatha temple built in $1458-59$ to Lord Parshavanath, the $23^{\text {rd }}$, and Mahaveer Swami temple built in various places of Gujarat and Karnataka to the Great Hero Mahavira

In Bangladesh, there is growing evidence for the presence of Jainism It is said that Huen-tsang, a Chinese pilgrim in the $7^{\text {th }}$ ca A.D found many Digambar monks in Pundravardhana Archaeological remains also testify the practice of Jainism in Bangladesh Alexander Cunningham first discovered a Jain idol at Mahasthangash in 1879 Another scientific evidence for Jainism to be a living religion in Bangladesh is the Jain temple at Dinajpur

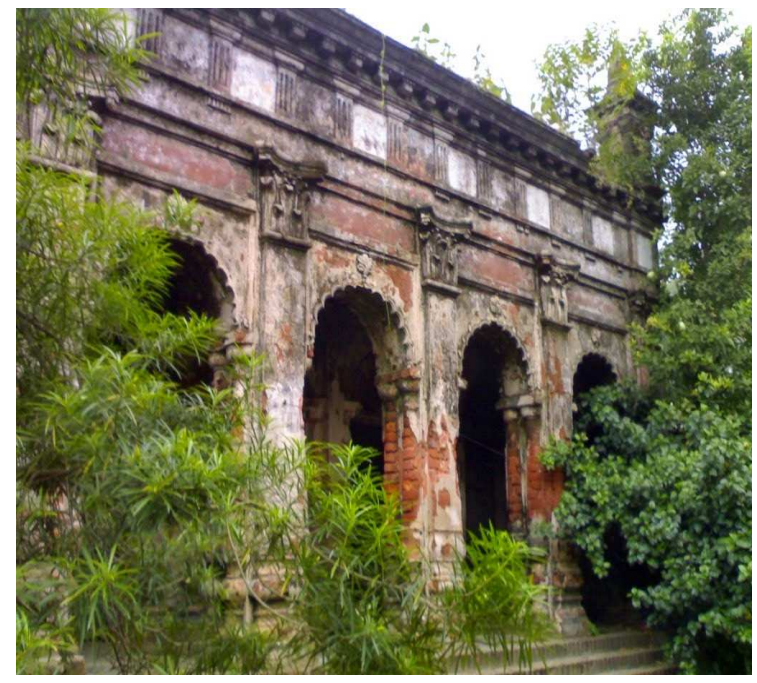

Source: http://bangladeshtemples. blogspot.com/2015/02/jain-temple-dinajpurbangladesh.html

Figure 1: Jain Temple, Dinajpur

\section{JAINISM IN ARCHAEOLOGICAL SITES OF VIETNAM}

Vietnam is located in the eastern coast of Mainland Southeast Asia The area is of $332,000 \mathrm{~km}^{2}$ and the population of 90 million people ${ }^{3}$ Vietnam has 54 ethnic groups in which the Viet is the majority, accounting for up to $85 \%$ of the total population At the beginning, the North Region (the Red River Delta) has been the racial and cultural cradle of Vietnam, where the majority Viet have been living Throughout history, Vietnam has expanded its territory over the South to form its country shape as seen today Vietnamese culture passed three major periods, including (1) the cultural formation period (Lac Viet cultural formation period) from prehistoric time to BCE 111, (2) the period of disputes and cultural exchanges with China and India, and (3) the period of dispute and cultural exchange with the west [Nguyen Ngoc Tho 2016, p.646] Tho (2016) claimed that the cultural exchanges with China are the deepest However, I think the cultural exchanges with India since the $5^{\text {th }}$ century B.C upto the $6^{\text {th }}$ century A.D are as profound as that of China These cultural contacts have left many imprints and vestiges across Vietnam, especially the vestiges of Indian architecture, sculptures, and religion In the

\footnotetext{
${ }^{3}$ Vietnam Bureau of Statistics, 2014.
} 
North, we can identify the architecture of Ajanta cave style in many temples such as Hong Phuc Temple, Linh Quang and Lien Phai in Ha Noi (Capital of Vietnam today) Many sculptures of kinnary, Vajapani, Lokepala, and garuda are found in these temples, which show the Indian influences in Vietnamese architecture Nonetheless, the most Indian imprints can be found in the archaeological sites of Vietnam like Champa in Nha Trang province, Oc Eo in An Giang province and recently found Cat Tien in Lam Dong, a highland province where many historians and archaeologists claim to have found and proved the cultural contacts between Vietnam and India in the past, as a result Vietnam has received Indian culture in terms of art and religion However, through these vestiges, I would like to find whether there is the Jainism imprints in these places Because, no scholars and researchers could identify and recognize Jainism culture When they found any Indian vestiges they just claim that they belong to either Hinduism or Buddhism only As we know the Jains are among successful traders and merchants, they travel a lot and have builtlarge Jain communities in the globe There are many Jainism sites across India and other countries like Borobudur (Indonesia), Angkor wat (Cambodia), Dinajpur (Bangladesh), etc

\section{Imprints of Jainism in Oc Eo Archaeological Site}

Oc Eo archaeological site is located in An Giang province, Vietnam It belonged to Funan kingdom $\left(1^{\text {st }}-7^{\text {th }} \mathrm{CE}\right)$ which in its golden age covered a large region including most of Southeast Asian countries such as South of Vietnam, Cambodia, Southeast and West Thailand, South of Laos, and the extreme South of Malaysia ${ }^{4}$ The center of Funan kingdom was claimed to be in the South of Vietnam today and Oc Eo was considered the economic and cultural center of Funan P.Pelliot (1903) translated Chinese letters about Funan kingdom and claimed that Funan was an Indianized powerful country Other French researchers like Parmentier, Claeys, Malleret, Coedes, Lajonquiere, etc , found archaeological sites in Mekong Delta and proved there was an ancient culture since the $1^{\text {st }}$ century A.D and those sites belonged to Funan kingdom Recently, Vietnamese archaeologists and historians have proved that Funan was a power, an empire at the time and it had three subkingdoms i. e Naravaranagara, capital of Funan situated in Ba The-Oc Eo, An Giang province, Kurumbanagara in Mekong Delta and Cat Tien in highland Lam Dong province [Luong Ninh 2005, p.57]

In addition to many sculptures that are considered to be Vishnu and Shiva in Hinduism, their symbols like linga, trident, gold leaves, etc , and many architectures of this religion found in Oc Eo, archaeologists have found a swastika, a symbol of Jainism in Go Thap, one of the archaeological sites of Oc Eo culture They identified the bricks of the architecture were arranged in the shape of swastika, 0.32m high and 0.4m width [Dang Van Thang 2016, p 31] The symbol Swastika of Jainism means different gates to enter the universe, it also refers to infinite knowledge, happiness and energy According to Tran Ngoc Them (2014), Buddhism has two symbols i. e swastika and charka, but Swastika first appeared before Buddhism and later Buddhism borrowed this symbol as in the beginning, Buddhism did not have any symbols nor sculptures Buddhism uses swastika to refer to happiness and prosperity; it is a nonstop motion. On the other hand, Slaczka (2011) in the work of The Bricks structures of Go Thap - Tombs or Temples? found many symbols that belonged to Jainism not Hinduism as many other archaeologists thought previously In his research, Slaczka found 20 gold leaves engraved with turtle shape, 15 leaves with elephants, 12 leaves with nandi and numerous lotus [p.78] He also found a symbol of naga and I think they belong to Jainism

${ }^{4}$ Chinese Encyclopedia - China History I. Funan (1992), Bejing Publisher, p. 233 
Cat Tien site was discovered in 1986, since then it has been excavated in the periods of 1994-2000 and 2001-2006 There are many architectures left but in ruined state However, archaeologists found many relics that bear Indian imprints such as linga, yoni, Uma sculpture standing on a buffalo, silver box engraved with a simha (lion), etc Especially they found a large gold leave engraved with a seven-headed naga bent into a $\mathrm{C}$-shape and elephant sculptures at architecture registered number 3 According to archaeologists, the seven-headed naga and elephants related to Buddhism as they are signs of protecting Buddha's relics However, I think that they must be the imprints of Jainism in Cat Tien

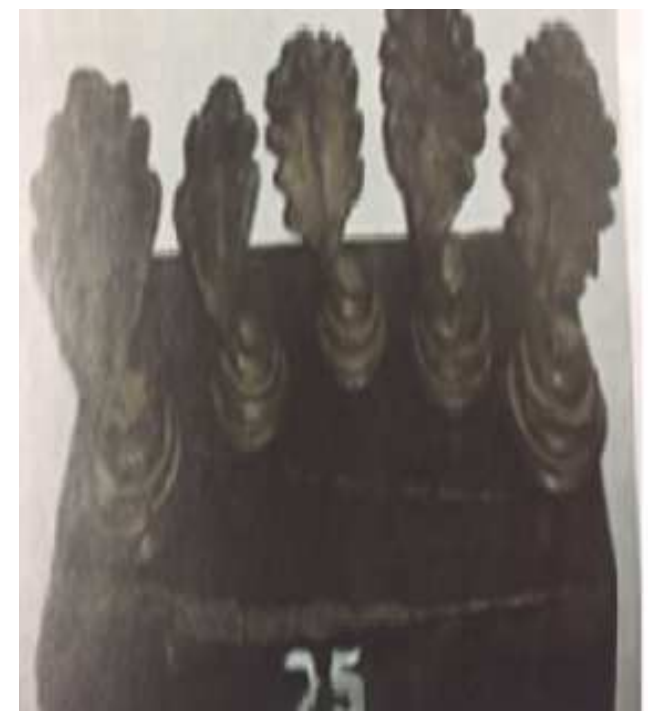

Source: Anna Slaczka (2011)

Figure 2 : Naga In Cobras, Anuradhapura Museum

\section{Imprints of Jainism in Champa Archaeological Site}

Champa is a Sanskrit name of the most important ancient kingdom of Vietnam, it was known as Lin-yi according to Chinese records It covered present day central and southern Vietnam and was contemporaneous with Funan kingdom Though the boundaries of Champa kingdom kept changing from time to time due to political reasons, the present province of Quang nam, Quang Ngai, Binh Dinh, Phan Rang and Binh Thuan constituted the core of the Champa kingdom The Indo-Champa interaction started since the rise of Cham dynasty in the $2^{\text {nd }}$ century $\mathrm{C}$. E The Indian contacts with Champa, like other Southeast Asian countries, commenced with mercantile trade The Indian looked for spices, timber, semi-precious stones that were in high demand of East Mediterranean countries; the Chams were actively participating in maritime trade Their items of exports were lead, tin, precious timber, woven cloth and porcelain ware According to Mishra P. P, one of the trade routes between India and China passed through Central and Southern Vietnam in which Oc Eo port and Champa played a crucial role [Mishra P. P 2004, p 292] As a result, cultural exchanges took place and Champa along with Oc Eo had received their ideology from India The influence of Indian religions on the life of the Champa people could be seen through their art and architecture of temples, sculptures of various Brahmanical gods and goddesses, images of Buddha and Bodhisttavas, monasteries, inscriptions and literary works, etc.

Based on the available sources, many scholars claim that Champa has been under influence of Brahmanism as reflected in the politico-social life, religious beliefs, literature, art and architecture of Champa kingdom, which are remained today in its important political centers such as Kauthura (Nha Trang province), Vijaya (Binh Dinh province) and Pandurauga (Phan Rang province) Kings of Champa had Indian names like Bradravarman, Shambhuvarman, Indravarman 
and Harivarman Champa showed the popularity of the concept of Trinity of Brahma-Vishnu-Shiva Among the Trinity, Shiva occupies the supreme position in the hierarchy It is proved thatof 130 inscriptions recovered in Champa 92 refer to Shiva, the Gods and Goddesses associated with him, 03 refer to Vishnu and 05 to Brahma while 02 refer to both Shiva and Vishnu [Dawee da Weewarn, p 52] Two principal groups of temples at My Son and Po-Nagar in ancient Champa are dedicated to Shavite Gods In addition to Shiva, other sculpturesthat have been found in Champa are identified with Vishnu by archaeologists Besides, other images such as Yakshas, Kinnars, Apsaras, Kartikay, Narayana, Purushotama, Hari, Govinda, Madhava have also been found in here Although the Chams followed Brahmanism and the Brahmanical influence has been quite deep in terms of religion, like Indians, they believed in karma, rebirth and impermanence of the world (Kshanbhangur), which is the basic cosmos of Jainism.

Later around the $9^{\text {th }}$ century C.E, Buddhism spread to Champa and soon, it became a very popular religion among the Chams both the elite and the commoners Since the Buddhism appeared in Champa, it showed the religious tolerance, which is the typical characteristic of Jainism Buddhism in Champa led to the unification of different religious strands There was a growing evidence that two monasteries and two temples of Jina (Jina Shankarayo) were converted into Buddhist and Shavite function by Samanta Based on this evidence, I think that there used to be Jainism in Champa kingdom, but due to the popularity of Brahmanism and Buddhism and the religious tolerance, Jainism had intermingled into the other two, just like the case of India Moreover, there are many inscriptions left in Champa sitesshowing the teaching principles of Jainism rather than Buddhism L.Finot interpreted the content of the inscriptions as preaching the people to love others, not do harm to any beings, do charity and donate their properties because there is karma and a cycle of birth and rebirth [Le Dinh Phung 2013, p 167].

Another scientific evidence of Jainism in Champa is the image of Naga, a poisonous snake became a holy naga to protect its Gods Archaeologists found a man seating in a padmasana, an ultimate meditation pose without any signs of clothes under a headed naga in sculptures and reliefs of Champa This sculpture is now kept in Cham Museum

\section{CONCLUSIONS}

Vietnam culture reflects its tolerant character, it imports many religions in the world All religions and indigenous beliefs exist in harmony During the course of history, it proved the import of BrahmanismandBuddhism in Champa, Oc Eo cultureand Cat Tien, which is considered to belong to Oc Eo culture So was the case of Jainism in relation with other religions in Vietnam Although there are not many imprints of Jainism left, we found some typical evidence for its availability in Vietnam They are the Chams' belief in karma and cycle of birth, sculpture of a man seating in a mediation yoga pose (padmasana pose), images of naga in Cham sculptures and reliefs There is an evidence of converting two Jina monasteries and temples into Buddhism In Oc Eo and Cat Tien, we also found vestiges of Jainism such as a sign of swastika in their architecture, image of naga, etc.

Why are therenot many symbols of Jainism left in these places as compared to other religions like Buddhism and Brahmanism, but it still shows the mark of the former? Maybe similar to the case of India, many monuments and idols of Jainism were destroyed and Jain temples were converted into Hinduism and Buddhism Jainism did not leave behind many temples and architectures due to their concept of building temple that would kill creatures Hence, Jains are vegetarian and nonviolent Most Jain art and architecture refer to ahimsa Jains create paintings to depict Jain universe Jain cosmos is divided into three realms of virtually unfathomable proportions: the upper or celestial world, the middle or mortal world 
and the lower or infernal world It shows Jains had complicated views on the world. Most architecture of Jainism existed around the $8^{\text {th }}$ century onwards.

In case of Champa and Oc Eo, along with mercantile the Indian traders also carried with them their religious beliefs and practices which in turn evoked the attention of the upper class of the society There were numerous ideas both in Brahmanism and Buddhism that served the interests of both rulers and the well-offs, that is the reason why the influence of Brahmanism and Buddhism started appearing first on the ruling class and the elite section of the society before it started trickling down to the common people While Jainism preaches ahima both in action and in thought, do charity to the need, not do harm to any beings, the Jains must practice the right believe, right knowledge and right behavior

Based on my research, I found that many Cham subkingdoms such as Indrapura and Vijaya have sculptures and architectures that have not been interpretedand deciphered thoroughly yet by archaeologists and historians whether they belonged to Buddhism or else? So we need to study more to have clear understanding about Champa culture as well as discovering Jainism imprints in Vietnam.

\section{REFERENCES}

1. Dahiya (2013), Dynamics of cultural interaction between India and Champa, Proceedings of Conference on Indian imprints in Vietnam and Southeast Asian countries, HCMC: National University Publishing House

2. Jain (2018), Jainism in Foreign countries, New Delhi: Shri Bharatvarshiya Digambaer Jain Mahasabha Publisher

3. Mishra P. P (2004), A Discourse on Indo-South East Asian Relations: Prejudices Problems and perception in proceedings of the Indian History Congress, $65^{\text {th }}$ Session

4. ISCC P.237, No XXV, Cf Law, B.C Buddhist Studies, Varanasi 983

5. Le Dinh Phung (2013), Indian Cultural Influence in Vietnam in History, Proceedings of Conference on Indian imprints in Vietnam and Southeast Asian countries, HCMC: National University Publishing House

6. Hussain, $G$, \& Mohyuddin, A Historical Sketch Of Peasant Activism: Tracing Emancipatory Political Strategies Of Peasant Activists Of Sindh.

7. Luong Ninh (2005), Funan Kingdom, Ha Noi: Culture and Information Publisher

8. Dang van Thang (2016), Temples at Go Thap, Dong Thap province, HCMC: Culture and Art Publisher

9. Slaczka (2011), The Brick Architecture of go Thap - Tombs or temples, translated by Le Thi Sinh Hien, HCMC: Culture and arts Publisher

10. Chinese Encyclopedia - China History I Funan (1992), Bejing Publisher

11. Vietnam Bureau of Statistics, 2014.

12. Nguyen Ngoc Tho (2016), Confucianism and humane education in contemporary Vietnam, Int Commun Chin Cult (2016) 3(4):645-6 71 DOI 10.1007/s40636-016-0076-8 